\title{
SEM Approach: Reclassifying Housing Delay in Malaysian Housing Industry
}

\author{
Chang Saar Chai and Aminah Md Yusof
}

\begin{abstract}
This paper sets out to study, define and reclassify delay in housing delivery system in Malaysia. In the recent years, the issues of delay related to housing and its development are gradually increasing in particular the housing project in Malaysia although the traditional delay factors have been applied to tackle this problem. Therefore, there is a strong need to reorganized and reclassified the delay factors in order to find an effective resolution and way out to solve the problems. This research was carried out through both primary and secondary sources. Triangulation approach has been utilized, in which quantitative method is used to collect data whereas qualitative method is essential to be used for data validation. Based on the data collected, a Structural Equation Modeling (SEM) model has been form, showing the relationship of structural delay, institutional delay and cultural delay in relation to housing delivery. From the study conducted, it is found that institutional delay is the major contributor to housing delay in Malaysia. Through the data validation of housing delay index, the study concluded that the Malaysian housing industry is currently experiencing moderate delay. The results from this study would help construction practitioners, developer, consultants, contractors, policy makers, and researchers to have a deep understanding on the delays factors caused in construction process so that proper mitigation measures could be taken place.
\end{abstract}

Index Terms-Delay classification, Malaysian housing delay, housing delay index, structural equation modeling

\section{INTRODUCTION}

Construction industry is known as the driving force behind most businesses to boost up the economics of country especially in Malaysia. In this regard, it is a great challenge for the construction industry because it plays significant role to create wealth, improve the life quality of the citizens via the provision of social and economic infrastructures and it connects the whole economy spectrum with a multiplier consequence that makes other industries to prosper alongside. Hillebrandt [1] stated that the construction industry, by nature, has many special problems. It can also be said that delay is the major issues and costly problem in construction industry as it decelerates the growth of the nation's economic development. This can be supported by Hamzah [2] that "Delays still occur in construction projects as the industry is famed for poor risk management, with many projects failing

Manuscript received October 25, 2013; revised December 24, 2013. This work was supported in part by the Innovative Construction Alliance, Faculty of Civil Engineering, Universiti Teknologi Malaysia.

Chang Saar Chai is with the Faculty of Civil Engineering, Universiti Teknologi Malaysia (e-mail: cschai2@live.utm.my).

Aminah Md Yusof is with the School of Graduate Studies, Universiti Teknologi Malaysia (e-mail: aminahyusof@utm.my). to meet deadlines and cost targets".

In Malaysia, Ministry of Housing and Local Government Malaysia [3] has emphasized some common issues associated to the discarded projects, delay in issuance certificate of fitness, delay in handing over, poor workmanship, interest charged by the developers because of late progressive payments, the unwillingness of developer to pay compensation for late delivery and payment problems related to maintenance in order to has a perceptible improvement in construction industry. Moreover, Ahmed [4] and Wa'el Alaghbari [5] claim that the possible factors that lead to delays in Malaysian construction projects are financial problems such as financial problems of clients (economic problems, financial difficulties and delayed payments), external factor of poor economic conditions (inflation rate) and cash flow problems of contractors. On the other hand, due to lack of comprehensive analysis on the sources and how the problem should be addresses, the delay problems arise easily. Therefore, the causes of delay should be focused and drawn attention through analyzing and classifying so that an accessible and approachable manner is expected.

This paper is outlined as follows. First of all, a great deal of information regarded with construction delays clarification may be found in the literature review to present a clear view about delays. Secondly, research methodology is explained on how the survey is conducted. The next section is followed by research findings in which analysis and discussion are discussed in detailed way. Lastly, the paper concludes with a brief summary of findings and the new classification of housing delays.

\section{LITERATURE REVIEW}

Recently, there are many studies related to construction projects have been investigated as the number of problems in construction projects experiencing delays are increasing because of various reasons. It is also believed by Alaghbari [6] that one of the most challengeable and complex troubles found in a construction project is delay. Ahmed et al. (2003) also agreed that delay is viewed as a worldwide and universal phenomenon.

According to Sadi and Sadiq [7], in the viewpoint of construction, delay is regarded as an unexpected of the extension of time beyond the date of completion in an agreement or beyond the agreed period that the parties granted to deliver a project. Moreover, the projects in medium and large size face the problem of delay the most while the small projects are severe [8]. Besides that, in the research of Alaghbari [9], they claimed that financial 
problems and coordination problems were the main and second factors respectively that making delay problems often occur in construction projects in Malaysia. In the similar research, delays problem occurs in construction projects due to poor design and weak management and control [10].

Therefore, in order to reduce the impacts of delay events that many contractors always concern about, researchers have been encouraged to take action to meet this challenge, and thus it is a necessary to have a greater understanding of classification of delays. In this matter, delays can generally be classified into four categories, which are excusable, non-excusable and excusable with or without compensable [11]. Furthermore, according to Bramble and Callahan [12], the delay is grouped into three classes, which are excusable delays (compensable and non-compensable), non-excusable delays and concurrent delays. Similarly, there are four types of delays claimed by Theodore [13], which are critical or non-critical, excusable or non-excusable, and concurrent or non-concurrent as well as compensable or non-compensable

In this case, the researcher is trying to explicitly classify them into two main categorizations, which are traditional delay classification and modern delay classification. In general, internal / external, critical / non-critical and excusable / non-excusable are the category of traditional delay classification whilst structural, institutional and cultural are classified as modern delay classification (Table I).

TABLE I: DELAY CLASSIFICATIONS IN CONSTRUCTION INDUSTRY
\begin{tabular}{|l|l|}
\hline \multicolumn{2}{|c|}{ Delay Classification } \\
\hline Traditional delay classification & New delay classification \\
\hline internal/external, & structural, \\
critical/non-critical, and & institutional, and \\
excusable/non-excusable & cultural \\
\hline
\end{tabular}

\section{A. Traditional Delay Classification}

According to Sambasivan and Soon [14], delay in construction becomes universal phenomenon, resulting in the construction industry and overall countries' economy to be influenced seriously [15]. This kind of delay problems, from time to time, still exist and occur frequently notwithstanding the traditional delay classification has seemingly reflected a complete understanding of delay factors to improve work process and quality of the projects through research and examining alternative methods and ideas.

Terry Williams revealed that there are three basic ways to classify delays: (i) Excusable delay with compensation, (ii) Excusable delay without compensation, and (iii) Non-excusable delay. A comprehensive classification of causes of construction delays has also been recommended by Abd. Majid and McCaffer [16] classified the factor of causes of non-excusable delays into twelve groups: financial-related delays; labor-related delays; improper planning; technical personnel shortages; lack of control; poor coordination; material-related delays; inadequate supervision; equipment-related delays; improper construction methods; poor communication and subcontractor-related delays. Meanwhile, the court case of Royal Brompton Hospital NHS Trust v Hammond \& Others (2000) described concurrent delay as: "Two or more delay events occurring within the same time period, each independently affecting the Completion Date."

Delays are also sorted by Ahmed [4] into two groups which are internal causes and external causes. In brief, internal causes come out from the parties to the contract, for instance, contractor, consultant and client. On the contrary, external causes arise from actions or events beyond the management and control of the related parties, for example the act of God or natural disaster, material suppliers or providers and the action of the government.

With regard to critical and non-critical delays, there could be delay in some part of total performance stipulated as contract obligation. The delay interferes with the total time frame of the contract is known as critical delay while non-critical delay is the delay which does not interfere with the total time frame of the contract. In short, critical delays take place when the delay has affected the completion of the project while delay that does not bring impact to the completion of the project is known as non-critical delays. The completion of the project is affected once the activities are delayed. These activities are the project itself, the plan or schedule of the contractors, the demands of the contract for sequence and phasing and the project's physical constraint.

The new delay classification in term of structural, institutional and cultural is defined and classified in order to provide a new different way and perspective toward the issues of delay in construction projects. This definitely helps to identify and recognize the factors of delay in a detailed way as well. The reason is the new classification of the delay will look into the structures of the project organization, the institutional influences and the behavior of the players involved. Undoubtedly, in this way, a more useful, productive and effective mitigation plan will be adopted; therefore, it is essential in the reclassification of delay even though the definition of structural, institutional and cultural delay has not been explicitly determined. Before the new classification is identified, there is a need to be familiar and know better the fundamental of the definition of structural, institutional and cultural.

\section{B. New Delay Classification}

Structural Delay: Structure is given description in Oxford Dictionary as the relationship between the elements like procedures, members (people), factors, steps, processes, parts and so on of something complex which constructed from a number of differential parts. According to Business Dictionary, structure is the identifiable elements in a system or a particular organization, which is referred to components, entities, factors, members, parts, steps, and other which form the stability of the organization. The Free Dictionary and Online Dictionary describe structure as the elements which had been put together in a particular way to form something and as a complex system which should be considered as a whole rather than of any single part of that particular organization or system respectively.

On the other hand, the term structural is defined as the relationship or the arrangement between the elements of housing sector in Oxford Dictionary. It is typically interdependence to the definition of "structure" in which the researchers claimed it as the relationship or connection of the 
elements in an organization or a system. In this regard, another definition is explained in Business Dictionary. It explains the structural variation is the organization or economy recurring change due to seasonal patterns or long time trends.

It could be obviously noticed that the term of "organization" is emphasized in the meaning of structure; hence, it is a necessary to look into and explore this term in the process of formulating a new classification of delay. Organization means as a group of people with particular interest in Oxford Dictionary. An organization is a social entity that possesses a collective target and is connected to an external environment in Wikipedia, the free encyclopedia. This includes non government bodies, governments, partnerships, cooperatives, corporations and others.

Moreover, the organizations in construction industry are segmented because the organizations' formation is impermanent and weak bonding between the related parties. In relation to this, through the representatives from the developers or planners, consultants and main contractor, as well as nominated sub contractor, the teams of project management or the teams of construction management are formed. Nonetheless, this kind of temporary team is usually defending their interests in the project organization while at the same time meeting the same target to complete the project successfully. As a result, due to the reason mentioned above, the project organizations are tentatively problematic-based.

To conclude this, based on the fundamental of "structure", the definition of structural delay is the delays where resulted from the organization itself, either system, managerial or structure deficiency which causing time overrun or postponement. In the case of structural delay in housing delivery system, the matters should be concerned are the delays in development approval stage, construction stage and handing over stage as well as organization such as developers or planners, consultants, and contractors as well as local authorities.

Institutional Delay: According to Geoffrey [21], social science research has widely been using the term of "institution", and thus reflecting that the use of the concept in other disciplines is wide-ranging, for instance economics, geography and sociology. Besides that, Oxford Dictionary defined the institution as an establishment of law or practices.

In term of sociology, institution is describes as a well established and structured pattern of behavior hips that been adopted as a part of a culture. It could be further defines as an established law, custom or social order in a particular society. With respect to housing delivery system, a set of rules and regulation has been regulated by the political institution of Malaysia with the purpose to guarantee and make sure a quality supply in housing production. In addition, National Housing Policies has broadly been introduced to delineate the basis of housing planning and development at federal and state as well as local levels. In other words, it provides comfortable, good quality, adequate, and affordable housing to improve the wellbeing of the citizens in accordance with Tenth Malaysia Plan (10MP) which aims in providing adequate, safe, healthy and harmonious living environment equipped with complete public amenities and recreation facilities (National Housing Policy Malaysia). Meanwhile, the full frame of Acts and Regulations is used not only to protect and shield the relevant parties but also to ensure the housing is delivered in legal and fair deal.

Some studies related to housing delays have showed that excessive Rules and Regulation results in the housing delays cases take place. This can be supported by Audit Commission of Great Britain [22] that delay in housing delivery is due to the incompetent of Local Authority in handling housing approval and confusion in housing planning framework.

As such, it could be concluded that the institution delay is the delay where is resulted from the process, discrepancies, uncertainties of the institutional evaluation in statutory requirement, procedure and approval, due to excessive Acts and Regulations to fulfill and obey. In India, according to Hemanta [23], technical and authority issues are the most complex and vital problem happen in construction projects. The reason is most of them overlook and disregard the duration taken for the development approval.

Cultural Delay: The behaviors, beliefs, values and symbols that are accepted by a group of people in their life is known as culture [24]. Generally, according to The Online Dictionary, culture is defined as a behavior or beliefs in a particular society which includes societal aspect like rules, norms, customs, products and others which treated as social norms. In addition, Anthropologist Edward B. Taylor [25] provides a broader definition; describe culture as the abilities and habits by the member in a society which includes belief, law, knowledge, custom, arts and so on.

Besides that, culture could be recognized as a set of behavior that the people embody culture in the elements of the organizations. These behaviors are the experience, values, philosophy, and belief that hold the organizational culture together. Moreover, the organization culture might be seem internally from the management decision making, monitoring, and controlling of the organization, especially in the junior level and middle executive level. It is also believed that each organizational culture is unique to the members in the organization and the features and characteristics might differ in the organization's departments, levels and members in reality. In addition, according to The Business Dictionary, the performance of the organizational culture is directly related to the business performance.

Regarding to this, cultural delay is the delays where results from the organizational culture such as behavior, practices, attitudes of the decision maker and interrelated to the organization structure in making decision. Fig. 1 shows a clear relationship of culture and organization via mathematic method. In brief, the organization is a subset to culture, illustrates that the elements of the organization formation brought different characteristic of culture. Therefore, it is believed that there are numerous possible factors that lead to cultural delay as each decision maker from different organizations is varied.

\section{RESEARCH Methodology}

The study is conducted over 160 construction practitioners in Malaysia, involved local authorities, developers, consultants and contractors. The questionnaires survey is analyzed by SPSS 18, indicates a high rank Cronbach's 
Alpha coefficient, recorded as 0.983. Meanwhile the KMO and Barlett's Test of Sphericity has demonstrated a high sampling adequacy of 0.822 . Principal Component Analysis (PCA) is performed by allowing threshold coefficient at 0.7 , indicates that only high factor loading factors will be extracted from 91 delay factors that have been identified by researchers. There are 36 delay factors have been extracted which shown in Appendix A. The extracted high factor loading factors is then computed delay classification model through AMOS 18.

\section{DATA ANALYSIS}

This study is to examine that the relationships of the structural delay, institutional delay and cultural delay in Malaysian housing industry. The formulation of housing delay model is meant to explain the existing delay factors experienced in Malaysia. The preliminary housing delay model is shown in Appendix B.

According to Box George [27], "essentially, all models are wrong, but some are useful". Therefore, the usefulness of the model should be testified, as this could be done by examine the Goodness of Fit (GoF) of a particular model. The relationships of the variables are considered valid only if the model passes the required threshold of GoF. At the meantime, there are two methods to improve the GoF, first by eliminate the low factor loading factors and second, applied Modification Indices (MI) to covary the similar characteristic variable in the model. The GoF of the delay classification model is shown in Table II meanwhile Fig. 1 illustrates the final model for delay classification in Malaysian housing industry.

TABLE II: GOODNESS OF FIT MODEL IMPROVEMENT RESULTS

\begin{tabular}{|l|c|c|c|}
\hline $\begin{array}{l}\text { Type of } \\
\text { Model Test }\end{array}$ & $\begin{array}{c}\text { Test } 1 \\
\text { (Preliminary) }\end{array}$ & $\begin{array}{c}\text { Test } 2 \\
\text { (Elimination) }\end{array}$ & $\begin{array}{c}\text { Test } 3 \\
\text { (MI) }\end{array}$ \\
\hline CMIN/DF & 4.021 & 2.181 & 1.583 \\
\hline GFI & 0.517 & 0.773 & 0.838 \\
\hline AGFI & 0.456 & 0.730 & 0.795 \\
\hline TLI & 0.610 & 0.849 & 0.948 \\
\hline CFI & 0.635 & 0.904 & 0.955 \\
\hline RMSEA & 0.138 & 0.086 & 0.061 \\
\hline
\end{tabular}

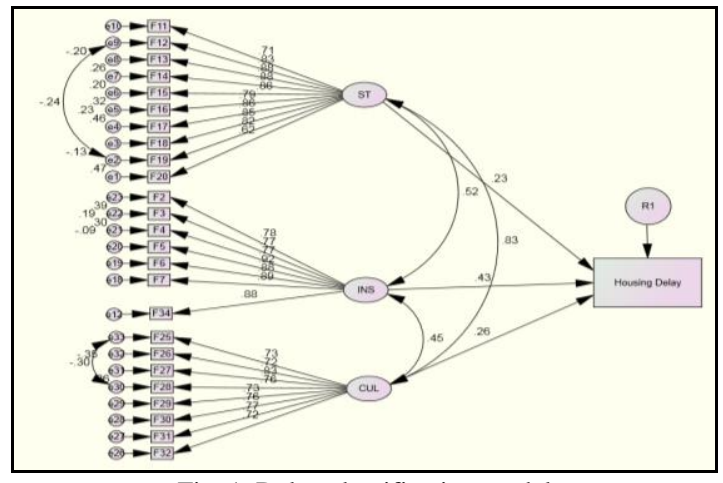

Fig. 1. Delay classification model

It is found that 11 delay factors have been eliminated from the final model during the elimination process. By referring to Fig-1 and Appendix A, it is found that structural delay and cultural delay have a strong relationship of 0.83 compared to others. This might due to the characteristic of the structural delay and cultural delay that organizational and managerial systems and human behavior are interrelated. The final model relationships are tabulated as shown in Table III.

TABLE III: STRUCTURAL EQUATION RESULTS FOR FINAL MODEL

\begin{tabular}{|l|c|c|}
\hline Constructs & $\begin{array}{c}\text { Standardized } \\
\text { Weights }\end{array}$ & Correlation \\
\hline Structural <--> Cultural & - & 0.83 \\
\hline Institutional<--> Structural & - & 0.52 \\
\hline Cultural <--> Institutional & - & 0.45 \\
\hline Structural --> H. Delay & 0.23 & - \\
\hline Institutional --> H. Delay & 0.43 & - \\
\hline Cultural --> H. Delay & 0.26 & - \\
\hline
\end{tabular}

The development of housing delay index utilized the standard regression weights of the final model. From Fig. 1, the housing delay is measure through structural delays, institutional delays and cultural delays. Therefore, a more fine grained approach has been adapted in this study to formulate the housing delay index. The relationships between housing delay and delay classifications are shown in Table IV.

TABLE IV: HOUSING DELAY AND ITS CLASSIFICATION RELATIONSHIPS

\begin{tabular}{|l|l|}
\hline Relationships & Standardized Weight \\
\hline Housing Delay-->Structural (ST) & $0.23 * 0.83=0.19$ \\
\hline Housing Delay-->Institutional (INS) & $0.43 * 0.52=0.22$ \\
\hline Housing Delay-->Cultural (CUL) & $0.26 * 0.45=0.12$ \\
\hline
\end{tabular}

Based on the results shown in SEM model, it can be concluded that housing delivery delay index is a function of summation in delay factors. The housing delivery delay index equation is formed as follows:

$$
\text { Housing delay index }=\int(S T, I N S, C U L)
$$

From (1),

Housing delay index $=0.19 \mathrm{ST}+0.22 \mathrm{INS}+0.12 \mathrm{CU}$

The equation is then converted to a common value system, in order to evaluate the level of delay in the project by following the rating scale created. This can be achieved through mathematical approach by dividing the standardized weight with the total standardized weight in the particular equation. The final equation is shown as follows:

From (2),

Housing delay index $=0.35 S T+0.42 I N S+0.23 C U L$

TABLE V: DELAY INDEX RATING SCALE

\begin{tabular}{|c|c|c|c|c|c|}
\hline Scale & 1 & 2 & 3 & 4 & 5 \\
\hline $\begin{array}{c}\text { Level } \\
\text { of } \\
\text { Delay }\end{array}$ & $\begin{array}{c}\text { Mild } \\
\text { Delay }\end{array}$ & $\begin{array}{c}\text { Moderate } \\
\text { Delay }\end{array}$ & $\begin{array}{c}\text { Severe } \\
\text { Delay }\end{array}$ & $\begin{array}{c}\text { Serious } \\
\text { Delay }\end{array}$ & $\begin{array}{c}\text { Extremely } \\
\text { Delay }\end{array}$ \\
\hline
\end{tabular}

The final stage of the study (See Table V) is to validate the housing delay index. The housing delay index has been presented to the practitioners in Malaysian housing industry, involved developers, consultants and contractors. Three case studies have been selected from the construction players to examine the functionality of the housing delay index. The background of the case studies is as follows:

Based on the input from the construction players (See Table VI), it is found that Malaysian housing industry is 
experienced an average of moderate delay in housing delivery. According to MHLG (2013), there are 31 housing projects are currently late in delivery meanwhile there are 191 sick projects officially reported to MHLG, regardless the unreported projects. Although the figures have been reduce compared to 2011 reported 50 late projects and 235 sick projects, however, the supply of housing is directly affect the housing ownership in the country as majority of the sick housing projects involved affordable housing program. As housing ownership has become a serious issue in Malaysia, the availability of housing, delivery of housing on time has become equally important this country.

TABLE VI: BACKGROUND OF CASE STUDIES

\begin{tabular}{|l|c|c|}
\hline Background & Case Study 1 & Case Study 2 \\
\hline Source of case study & Developer & Contractor \\
\hline Types of housing & Double storey terrace & Condominium \\
\hline Procurement method & Design and build & $\begin{array}{c}\text { Design and } \\
\text { build }\end{array}$ \\
\hline Numbers of Unit & 64 units & 150 Units \\
\hline Original contract sum & RM10,007,073.00 & - \\
\hline Final contract sum & RM9,615,870.24 & 24 months \\
\hline Duration of project & 16 Months & 1 October 2009 \\
\hline $\begin{array}{l}\text { Date } \\
\text { commencement }\end{array}$ & 18 th August 2008 & 5 March 2012 \\
\hline $\begin{array}{l}\text { Practical completion } \\
\text { date }\end{array}$ & 15 th March 2010 & 125 days \\
\hline Extension of time & 53 days & $17 \%$ \\
\hline Actual Delay (\%) & $11 \%$ & 3.23 \\
\hline Housing Delay Index & 2.33 & \\
\hline
\end{tabular}

\section{CONCLUSION AND RECOMMENDATIONS}

The development of housing delay index is meant to provide a new platform to evaluate the efficiency of the housing projects. Moreover, this index are trying to encourage the construction players to implement suitable mitigation measures to avoid housing delay as majority of the delay factors have been classified. The study is limited to Malaysia only and population sampling method has been applied. A wider range of study should be conducted to obtain more reliable data. Moreover, it is recommended to compute delay mitigation index as well, in order to compare with housing delay index to examine the performance of the existing housing projects.

\section{APPENDIX A}

*DA=Development Approval, CON=Construction, $\mathrm{HO}=$ Handing Over

\begin{tabular}{|c|l|c|c|c|c|}
\hline \multirow{2}{*}{ ID } & \multirow{2}{*}{ Delay Factors } & \multicolumn{2}{|c|}{ Housing Delivery Stages } & \multicolumn{1}{c|}{$\begin{array}{c}\text { Delay } \\
\text { Classificati } \\
\text { on }\end{array}$} \\
\cline { 2 - 5 } F1 & $\begin{array}{l}\text { Delays in Municipal } \\
\text { Procurement } \\
\text { Processes for Project }\end{array}$ & 0.758 & CON & HO & Structural \\
\hline F2 & $\begin{array}{l}\text { Delay in Utilities } \\
\text { Approval }\end{array}$ & 0.721 & & & Institutional \\
\hline F3 & $\begin{array}{l}\text { Uncertainty } \\
\text { Statutory } \\
\text { Requirements }\end{array}$ & 0.709 & & & Institutional \\
\hline F4 & $\begin{array}{l}\text { Long Decision } \\
\text { Making Duration }\end{array}$ & 0.796 & & & Institutional \\
\hline F5 & $\begin{array}{l}\text { Improper } \\
\text { Documentation }\end{array}$ & 0.799 & & & Institutional \\
\hline
\end{tabular}

\begin{tabular}{|c|c|c|c|c|c|}
\hline F6 & $\begin{array}{lr}\text { Needs for } & \text { Approval } \\
\text { from } & \text { Other } \\
\text { Department } & \\
\end{array}$ & 0.765 & & & Institutional \\
\hline F7 & 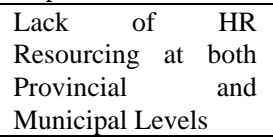 & 0.757 & & & Institutional \\
\hline F8 & $\begin{array}{l}\text { Delay in Decision } \\
\text { Making by LA }\end{array}$ & 0.777 & & & Cultural \\
\hline F9 & $\begin{array}{l}\text { Delay in Decision } \\
\text { Making by Developer }\end{array}$ & 0.731 & & & Cultural \\
\hline F10 & $\begin{array}{lr}\text { Late in Reviewing } \\
\text { and } & \text { Approving } \\
\text { design Documents }\end{array}$ & 0.726 & & & Cultural \\
\hline F11 & Obsolete Technology & & 0.750 & & Structural \\
\hline $\mathrm{F} 12$ & $\begin{array}{ll}\text { Delay in Site } \\
\text { Mobilization }\end{array}$ & & 0.762 & & Structural \\
\hline F13 & $\begin{array}{ll}\text { Shortage } & \text { of } \\
\text { Equipment } & \\
\end{array}$ & & 0.770 & & Structural \\
\hline F14 & $\begin{array}{l}\text { Incompetent } \\
\text { Machineries Operator } \\
\text { Skill }\end{array}$ & & 0.773 & & Structural \\
\hline F15 & $\begin{array}{l}\text { Low Productivity and } \\
\text { Efficiency of } \\
\text { Equipments }\end{array}$ & & 0.752 & & Structural \\
\hline F16 & $\begin{array}{l}\text { Inappropriate } \\
\text { Construction } \\
\text { Methods }\end{array}$ & & 0.735 & & Structural \\
\hline F17 & $\begin{array}{l}\text { Unreliable } \\
\text { Subcontractor }\end{array}$ & & 0.740 & & Structural \\
\hline F18 & Site Labors Turnover & & 0.770 & & Structural \\
\hline F19 & Materials Shortage & & 0.779 & & Structural \\
\hline F20 & Shortage of Labors & & 0.740 & & Structural \\
\hline $\mathrm{F} 21$ & $\begin{array}{l}\text { Non Submission of } \\
\text { Individual } \\
\text { Beneficiary } \\
\text { Applications } \\
\text { Developers }\end{array}$ & & 0.704 & & Institutional \\
\hline F22 & $\begin{array}{l}\text { Extra Work Without } \\
\text { Approval }\end{array}$ & & 0.731 & & Institutional \\
\hline $\mathrm{F} 23$ & Nationality of Labors & & 0.719 & & Institutional \\
\hline F24 & $\begin{array}{l}\text { No Incentive for } \\
\text { Contractor }\end{array}$ & & 0.75 & & Institutional \\
\hline F25 & $\begin{array}{l}\text { Improper } \\
\text { Construction } \\
\text { Methods } \\
\text { Implemented }\end{array}$ & & 0.748 & & Cultural \\
\hline F26 & $\begin{array}{l}\text { Outdated Engineering } \\
\text { Design Software }\end{array}$ & & 0.724 & & Cultural \\
\hline F27 & $\begin{array}{l}\text { Accident During } \\
\text { Construction }\end{array}$ & & 0.735 & & Cultural \\
\hline F28 & $\begin{array}{l}\text { Low Productivity of } \\
\text { Labors }\end{array}$ & & 0.772 & & Cultural \\
\hline F29 & Rework & & 0.763 & & Cultural \\
\hline F30 & Handover Packaging & & 0.778 & & Cultural \\
\hline F31 & Appliances Defects & & 0.767 & & Cultural \\
\hline F32 & $\begin{array}{l}\text { Developer } \\
\text { Satisfaction }\end{array}$ & & 0.723 & & Cultural \\
\hline F33 & $\begin{array}{l}\text { Changes/Amendment } \\
\mathrm{s} \text { in Rules and } \\
\text { Regulations }\end{array}$ & & & 0.711 & Institutional \\
\hline F34 & Lack of Staff in LA & & & 0.723 & Institutional \\
\hline F35 & $\begin{array}{l}\text { Poor Communication } \\
\text { and Coordination }\end{array}$ & & & 0.718 & Cultural \\
\hline F36 & $\begin{array}{l}\text { Delay in Performing } \\
\text { Inspection and } \\
\text { Testing }\end{array}$ & & & 0.752 & Cultural \\
\hline \multicolumn{6}{|c|}{$\begin{array}{l}\text { Extraction Method: Principal Component Analysis. } \\
\text { Rotation Method: Varimax with Kaiser Normalization. }\end{array}$} \\
\hline & converoed in 6 ite & & & & \\
\hline
\end{tabular}




\section{APPENDIX B}

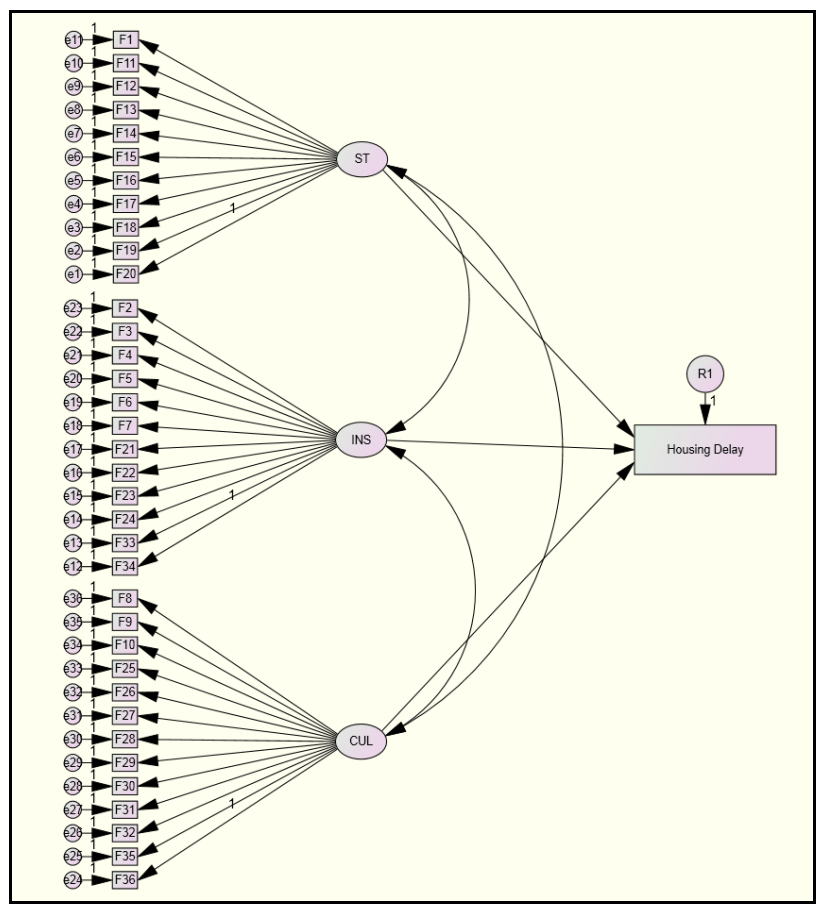

\section{REFERENCES}

[1] P. M. Hillebrandt, Economic Theory and the Construction Industry, Palgrave Macmillan, 2000.

[2] H. A. Rahman, R. Takim, and W. S. Min, "Financial-related causes contributing to project delays," Journal of Retail and Leisure Property, vol. 8, no. 3, pp. 225-238, 2009.

[3] Ministry of Housing and Local Government Malaysia, MHLG, 2007.

[4] S. M. Ahmed, S. Azhar, P. Kappagntula, and D. Gollapudial, "Delays in construction: a brief study of the florida construction industry," in Proc. the 39th Annual ASC Conference, Clemson University, Clemson, SC, pp. 257-266, 2003.

[5] W. A. M. A. Aghbari, "Factors affecting construction speed of industrialized building system in Malaysia," Master Thesis, University Putra Malaysia, 2005.

[6] W. Alaghbari et al., "The significant factors causing delay of building construction projects in Malaysia," Engineering, Construction and Architectural Management, vol. 14, no. 2, pp.192-206, 2007.

[7] S. A. Assaf and S. A. Hejji, "Causes of delay in large construction projects," International Journal of Project Management, vol. 24, pp. 349-357, 2005

[8] A. G. MA, "Delays in the construction of public utility projects in Saudi Arabia," Master thesis, CEM Dept., KFUPM, Dhahran, Saudi Arabia, 1995.

[9] A. K. S. Ernawati, "The significant factors causing delay of building construction projects in Malaysia," Engineering, Construction and Architectural Management, vol. 14, no. 2, 2007.

[1] R .Apolot H. Alinaitwe, and D. Tindiwensi, An Investigation into the Causes of Delay and Cost Overrun, in Uganda's Public Sector Construction Projects, MAK, 2011.

[2] K. Diekmann, "Concurrent delays in construction projects," Journal of Construction Engineering and Management, vol. 113, no. 4, pp. 591-602, 1987.

[3] B. Bramble and M. T .Callahan, Construction Delay Claims, New York: John Wiley, 1987.
[4] T. J. T. Jr, "Construction delays," Understanding Them Clearly, Analyzing Them Correctly, Butterworth-Heinemanm, 2nd Edition, 2009.

[5] M. Sambasivan and Y. W. Soon, "Causes and Effects of Delays in Malaysian Construction Industry," International Journal of Project Management, vol. 25, pp. 517-526, 2007.

[6] A. S. Faridi and S. M. E. Sayegh, "Significant factors causing delay in the UAE construction industry," Construction Management and Economics, Terry Williams, vol. 24, no. 11, pp. 1167-1176, 2003.

[7] M. Z. A. Majid and R. Caffer, "Factors of non-excusable delays that influence contractors' performance," Journal of Management in Engineering, ASCE, pp. 42-49, 1998.

[8] The Oxford Dictionary (n.d). [Online]. Available: http://www.oxforddictionaries.com.

[9] The Business Dictionary (n.d). [Online]. Available: http://www.businessdictionary.com/

[10] The Free Dictionary (n.d). [Online]. Available: http://en.wikipedia.org/wiki/TheFreeDictionary.com

[11] The Online Dictionary (n.d). [Online]. Available: http://dictionary.reference.com/

[12] G. M. Hodgson, "What Are Institution," Journal of Economic, no. 1, 2006 ,

[13] G. Britain, "National Audit Office and Great Britain: Audit Commission," Building More Affordable Homes: Improving the Delivery of Affordable Housing in Areas of High Demand, Norwich: The Stationery Office, 2005.

[14] H. Doloi, A. Sawhney, K. C. Iyer, and S. Rentala, “Analysing factors affecting delays in India construction projects," International Journal of project Management, vol. 30, 2012, pp. 479-489.

[15] G. Hofstede, Cultures and Organizations: Software of the Mind, London: McGraw-Hill, 1991.

[16] E. B. Taylor, Primitive Culture, 3d ed., vol. 1, 1889.

[17] J. Arbuckle, Amos 16.0 User's Guide, Chicago: SPSS, 2007.

[18] E. P. George and N. R. Draper, Empirical Model-Building and Response Surfaces, Wiley, pp. 424, 1987.

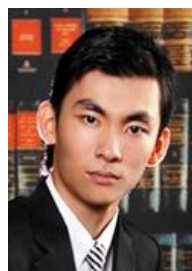

Chang Saar Chai comes from the Sarawak state of Malaysia, he was born in 1985. Chai had attained the bachelor of science construction management in 2008 from the Universiti Teknologi Malaysia. Next, in year 2009 , he awarded master in construction management in Faculty of Civil Engineering from the same university. He works at Singapore as senior engineer before holding the position of research officer at Universiti Teknologi Malaysia, at the same time pursuing his doctoral degree in the university. He is actively involves in housing research especially on housing delivery process and housing affordability in Malaysia. He had attended several conferences and scientific publications.

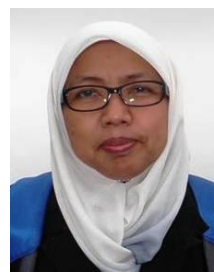

Aminah Md Yusof received her master degree in property management in Universiti Teknologi Malaysia, 1993. In year 1999, she awarded doctoral degree in University of Aberdeen, United Kingdom. She works for Universiti Teknologi malaysia since her graduation, holding position of lecturer, and next associate professor. At present, she is the academic manager of the School of Graduate Studies and associate professor in Faculty of Civil Engineering, Universiti Teknologi Malaysia. Her interests are concentrated on property management. Within this area, she is an author and co-author of 5 books on property management, contract management, as well as of over hundred scientific publications

Dr. Aminah is a member of Pacific Rim Real Estate Society since 2009 and become the Panel Expert National Property and Real Estate Research Coordinator since 2007. 